\title{
Post-fire regeneration in seasonally dry tropical forest fragments in southeastern Brazil
}

\author{
MAYKE B. COSTA ${ }^{1}$, LUIS FERNANDO T. DE MENEZES ${ }^{1}$ and MARCELO T. NASCIMENTO ${ }^{2}$ \\ ${ }^{1}$ Departamento de Ciências Agrárias e Biológicas, Universidade Federal do Espírito Santo, \\ Rodovia BR 101 Norte, Km 60, Litorâneo, 29932-540 São Mateus, ES, Brazil \\ ${ }^{2}$ Laboratório de Ciências Ambientais, Universidade Estadual do Norte Fluminense, Avenida Alberto \\ Lamego, 2000, Parque Califórnia, 28013-620 Campos dos Goytacazes, RJ, Brazil
}

Manuscript received on October 28, 2016; accepted for publication on July 31, 2017

\begin{abstract}
Seasonally dry tropical forest is one of the highly threatened biome. However, studies on the effect of fire on these tree communities are still scarce. In this context, a floristic and structural survey in three forest areas in the southeast of Brazil that were affected by fire between 14 and 25 years ago was performed with the objective of evaluating post-fire regeneration. In each site, five systematically placed plots ( 25 $\mathrm{m} \times 25 \mathrm{~m}$ each) were established. The more recently burnt site had significantly lower values of richness and diversity than the other two sites. However, the sites did not differ in density and basal area. Annona dolabripetala, Astronium concinnum, Joannesia princeps and Polyandrococos caudescens were within the 10 most important species for the three sites. Comparing these data with adjacent mature forests, the results indicated differences both in structural and floristic aspects, suggesting that the time after fire was not sufficient for recuperation of these areas. The recovery process indicate at least 190 years for areas return to basal area values close to those observed in mature forests nearby.
\end{abstract}

Key words: Atlantic forest, fire ecology, forest succession, forest structure, post-fire recovery.

\section{INTRODUCTION}

Seasonally dry tropical forest (SDTF), which shows high diversity, high endemism, and high floristic turnover, is currently considered one of the most highly threatened biome (Banda-R et al. 2016), with fire and fragmentation having important roles in this process (Janzen 1988, Miles et al. 2006) and approximately $42 \%$ of tropical forests are classified in this category (Murphy and Lugo 1986). However, the majority of studies on ecological succession

Correspondence to: Marcelo Trindade Nascimento

E-mail: mtn@uenf.br in tropical forests have been done in rain forests (Vieira and Scariot 2006).

Ecologically, fire is a natural phenomenon that is responsible for affecting ecosystem functioning and influencing forest composition and structure. The predictions of its impact on the vegetation are complex, since plants have different responses and diverse interactions with the environment and fauna (Libano and Felfili 2006).

In general, we can consider that the recovery process of a tropical forest after disturbance by a fire is highly dependent on seed sources provided by the surviving trees (forest islands) and by resprouting 
(Corlett and Primack 2011). Another important aspect is that the recovery time of the disturbed forest, is, in general, slow and depends upon the intensity of the disturbance and the surrounding vegetation. Saldarriaga and Uhl (1991) estimated that between 140 and 200 years were necessary for tracts abandoned slash-and-burn areas in humid tropical forest in the Venezuelan amazon to attain biomass similar to native forest. However, 45 years secondary seasonal forests attained values for biomass similar to surrounding native forests due to the resprouting capacity of the individuals after disturbance by fire (Oliveira-Filho et al. 2004).

Thus, understanding the recovery process of the structure and composition of the plant community and which variables control this process is a central question in tropical plant ecology. The complex interaction of the biotic and abiotic components and the limiting factors in secondary succession should be understood to aid in the management and priorization of decisions on the future necessities for conservation in this region (Powers et al. 2009), however, the principle mechanisms of succession and regeneration in these SDTF are still unexplored (Quesada et al. 2009).

The aim of this study was to determine the floristic and structural characteristics of forest fragments that were disturbed by fire between 14 and 25 years ago. Our specific questions were: (i) What is the response of species richness and diversity during the successional process after fire?; (ii) Is there a characteristic group of tree species in post-fire succession related to SDTF?

\section{MATERIALS AND METHODS}

\section{STUDY AREA}

The study was carried out in three forest areas that were burned, 14 years ago (Sooretama Biological Reserve, $\mathrm{SO}, 18^{\circ} 33^{\prime}$ to $19^{\circ} 05^{\prime} \mathrm{S} ; 39^{\circ} 55^{\prime}$ to $40^{\circ} 15^{\prime} \mathrm{O}$ ) and 25 years ago (Córrego do Veado Biological Reserve, $\mathrm{CV}, 18^{\circ} 16^{\prime}$ to $18^{\circ} 25^{\prime} \mathrm{S}$; $40^{\circ}$ $06^{\prime}$ to $40^{\circ} 12^{\prime} \mathrm{O}$ and Córrego Grande Biological Reserve, $\mathrm{CG}, 18^{\circ} 12^{\prime}$ to $18^{\circ} 18^{\prime} \mathrm{S}$; $39^{\circ} 45^{\prime}$ to $39^{\circ}$ $50^{\prime} \mathrm{O}$ ). All areas are located within conservation units in the northern part of the State of Espírito Santo, Brazil, and after the fire they have not been disturbed (Table I). The main forest type in this region is the Seasonally dry tropical forest (SDTF) or Seasonal Semideciduous forest in the Brazilian classification (IBGE 2012). According to the Köppen classification system (Köppen 1946), the climate of the region is type Awi (tropical wetdry isothermal). The mean annual rainfall is 1202 $\mathrm{mm}$, with the driest months between June and August. The mean annual temperature is $23.3^{\circ} \mathrm{C}$, the monthly mean ranging from $14.8^{\circ} \mathrm{C}$ to $34.2^{\circ} \mathrm{C}$ (Jesus et al. 2010). The predominant soil type in the region is Dystrophic Red-Yellow Latossol, but there also is significant proportion of Dystropic and Eutrophic Red-Yellow Argisoils (EMBRAPA 1978).

TABLE I

General information on the size of the studied forest fragments, size of area affected by the fire, date of fire, mean altitude, temperature (T) and mean annual precipitation (P) in the three forest fragments, Biological Reserve Sooretama (SO), Biological Reserve Córrego de Veado (CV) and Biological Reserve Córrego Grande (CGO), State of Espírito Santo, Brazil.

\begin{tabular}{ccccccc}
\hline Site & $\begin{array}{c}\text { Fragment Size } \\
(\text { ha })\end{array}$ & $\begin{array}{c}\text { Burned area } \\
\text { (ha) }\end{array}$ & Date of fire & Altitude $(\mathrm{m})$ & $\mathrm{T}\left({ }^{\circ} \mathrm{C}\right)$ & $\mathrm{P}(\mathrm{mm})$ \\
\hline SO & 27858 & 2500 & $8 / 1998$ & 113 & 25.8 & 1212 \\
CV & 2392 & 1913 & $10 / 1987$ & 106 & 24.1 & 1068 \\
CG & 1485 & 445 & $12 / 1987$ & 55 & 27.0 & 1300 \\
\hline
\end{tabular}


The fires in these three areas occurred in the dry season, during "El-Nino" events (ENSO) and were crown fires (high intensity) with high tree mortality post-fire.

\section{SAMPLING AND DATA ANALYSIS}

In June 2012 five plots (25 m x $25 \mathrm{~m}$ each) were systematically installed in each of the three study areas. All plots were in plateau areas that had suffered crown fires and were located at least a 50 $\mathrm{m}$ from the forest edge and did not include valleys or watercourses. The distance between plots ranged from 0.8 to $2.5 \mathrm{~km}$ in function of the shape and size of each forest area. The distance between the plots and the forest edge varied from 50 to $750 \mathrm{~m}$ depending of the study area.

In each plot the diameter and height of all individuals with a $\mathrm{DBH} \geq 5 \mathrm{~cm}$ were measured. Standing dead trees and the number of lianas on trees that had roots within the plot were also assessed to aid in the evaluation of the degree of disturbance in the fragments. The families were classified according to the APG IV system (APG IV 2016). Voucher specimens were incorporated at the herbarium SAMES of the Universidade Federal do Espírito Santo (UFES).

The species were classified into the ecological groups according to their successional status as pioneers, early secondary and late secondary (Gandolfi et al. 1995) based on our field experience and literature (Paula and Soares 2011). They were also grouped by dispersal syndrome. The dispersal syndrome was based on fruit/seed type, using the morphological criteria described by Van Der Pij1 (1982): zoochoric and abiotic (anemochoric and autochoric).

Differences in forest structure among the sites were evaluated using number of individuals $(\mathrm{N})$, number of bifurcated individuals (Birf) and number of standing dead trees (Stdead), total basal area (BA) and individual basal area (IBA), relative density (RD), relative dominance (RDo) and cover value (CV=RD+RDo) (Kent and Coker 1992).

The Shannon-Weiner diversity index (H') was calculated for each site along with comparisons of species richness and diversity using rarefaction curves based on the number of individuals sampled in each plot. All calculations were done using EcoSim 7 (Gotelli and Entsminger 2001).

Floristic similarity was calculated using Morisita's index based on species abundance (Brower and Zar 1984). A dendogram was generated by cluster analysis using UPGMA and an Analysis of Similarities (ANOSIM), using the software PAST v. 2.17c (Hammer et al. 2001), was run to test statistically whether there is a significant difference between two or more groups of sampling units.

The structural characteristics of the vegetation (density, basal area, volume, number of bifurcated individuals and number of standing dead trees), ecological groups and dispersal syndrome in the study area were compared using Analysis of Variance (ANOVA) after testing for normality of variance. When statistical differences were found between the means the Tukey's test was performed as a post hoc test (Brower and Zar 1984). These analyses were done using the software PAST v. 2.17c (Hammer et al. 2001).

The areas studied by Paula and Soares (2011) in the Biological Reserve Sooretama and by Jesus and Rolim (2005) in the Natural Reserve of Vale do Rio Doce near Linhares (ES), an adjacent area to the Biological Reserve Sooretama were used as reference since they are mature forests.

\section{RESULTS}

\section{IMPACT AND RECOVERY OF FLORISTIC} COMPOSITION

A total of 1248 individuals, distributed in 226 morphospecies, 137 genera and 49 families were found in the three study areas. It was possible to 

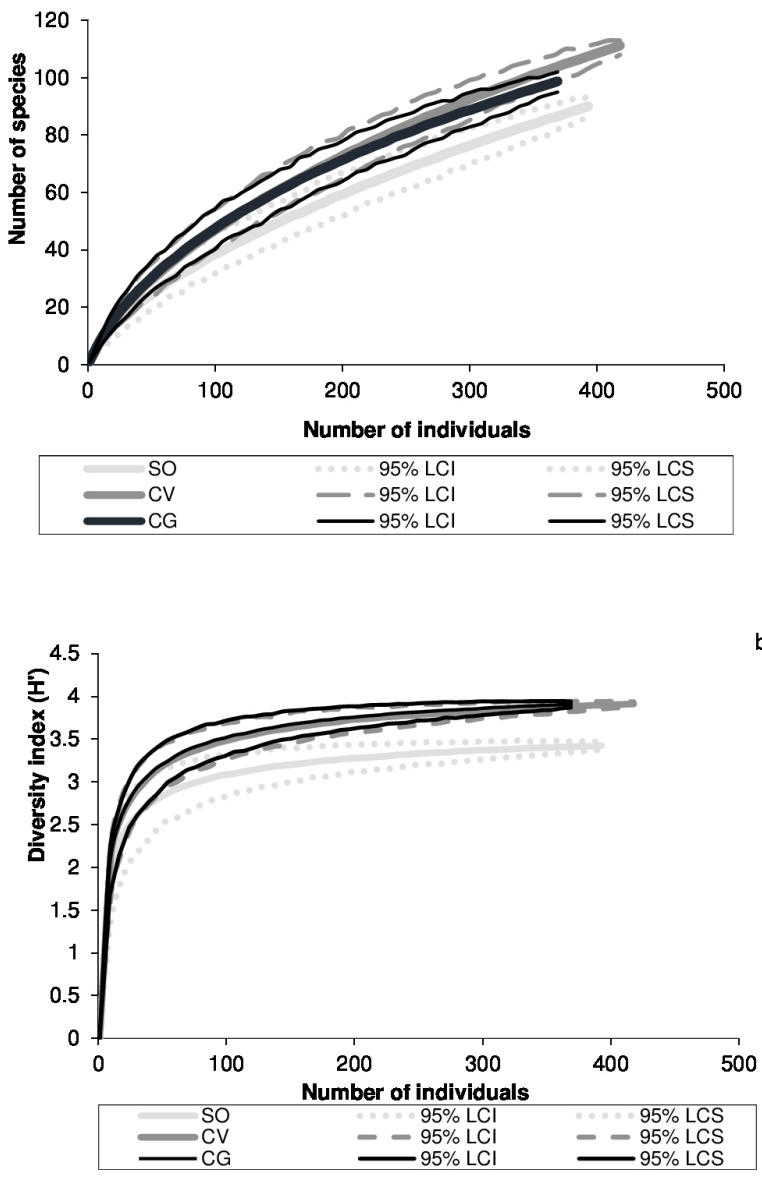

Figure 1 - Species rarefaction curves for richness (a) and for diversity H' (b) of tree species sampled in the forest fragments Sooretama (SO, 14 years after fire), Córrego do Veado (CV, 25 years after fire) and Córrego Grande (CG, 25 years after fire), ES, Brazil. Dotted lines are the upper and lower confidence intervals $(95 \%)$.

identify $200(88.5 \%)$ to species, $23(10.2 \%)$ only to genus and $3(1.3 \%)$ only to family. In general, Fabaceae was the family with the largest number of species in all of the study plots, however CG was the area with the least number of species in this family.

In relation to richness of tree species, $\mathrm{CV}$ had the highest number of species (113) of which 56 (49.5\%) were exclusive to this site. CG had 102 species with $63(61.8 \%)$ being exclusive to this site and $\mathrm{SO}$, the site with the lowest richness, had 94 species of which only 37 (39.4\%) were exclusive.

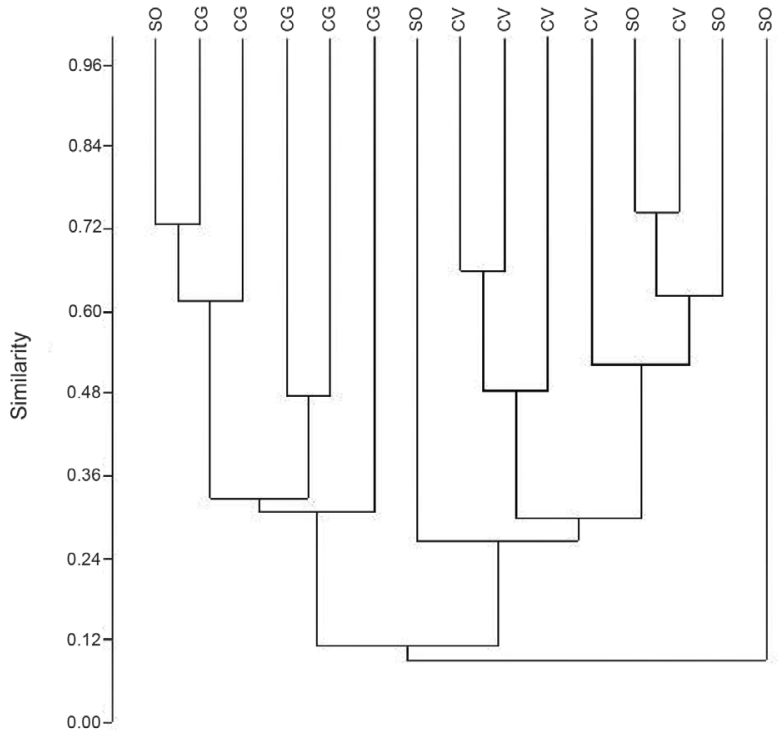

Figure 2 - Dendrogram of floristic similarity using Morisita's Index for plots of the burnt forest fragments (Cophenetic correlation= 0.87). (Sooretama, SO, 14-yrs after fire, Córrego do Veado, CV, 25-yrs after fire and Córrego Grande, CG, 25 yrs after fire).

The two sites with a longer post-fire history, CV and $\mathrm{CG}$, did not significantly differ in either species richness or species diversity. The site with the more recent fire, $\mathrm{SO}$, had significantly lower values than the other two sites (Fig. 1).

The floristic similarity varied among the areas, with a larger floristic difference between $\mathrm{CG}$ and the other two sites (CV and SO). The dendrogram showed that $\mathrm{CG}$ formed a group, isolated and significantly different (ANOSIM, R=0.53 $\mathrm{p} \leq$ 0.001 ) from those $\mathrm{CV}$ and most $\mathrm{SO}$ groups (Fig. 2). No strong relationship was observed between time after fire and floristic similarity in these sites. Tree similarities among burnt forest fragments and the mature forest were very low and varied from $2.5 \%$ ( $\mathrm{SO}$ vs mature) to $8.4 \%$ (CG vs mature).

Overall, $11.4 \%$ of the species were pioneers, $41.3 \%$ were early secondary and $47.3 \%$ were late secondary species, quite distinct from the values observed in mature forests (Fig. 3). In all three areas, a low percentage of pioneer species was observed, with values always lower than $20 \%$. 


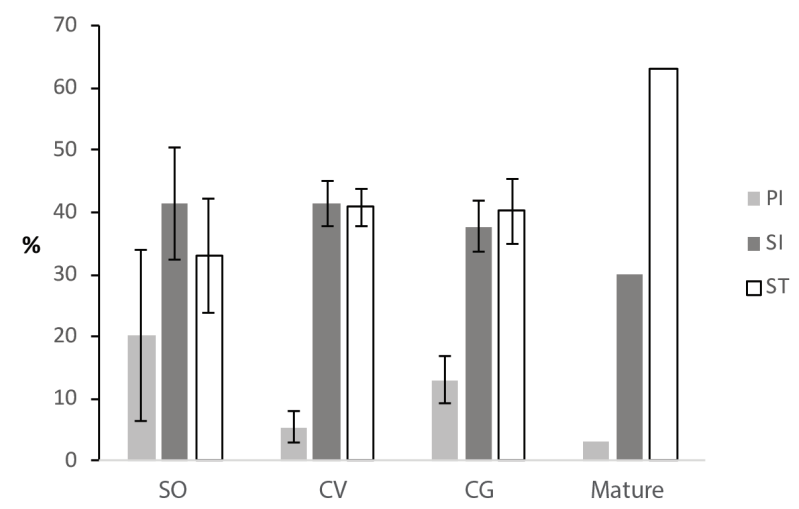

Figure 3 - Distribution of the percentage of species in ecological groups in the burnt forest fragments Sooretama (SO, 14-yrs after fire), Córrego do Veado (CV, 25-yrs after fire), Córrego Grande (CG, 25-yrs after fire) and an adjacent mature forest (Paula and Soares 2011), State of Espírito Santo, Brazil. PI - pioneers, SI - early secondary and ST - late secondary.

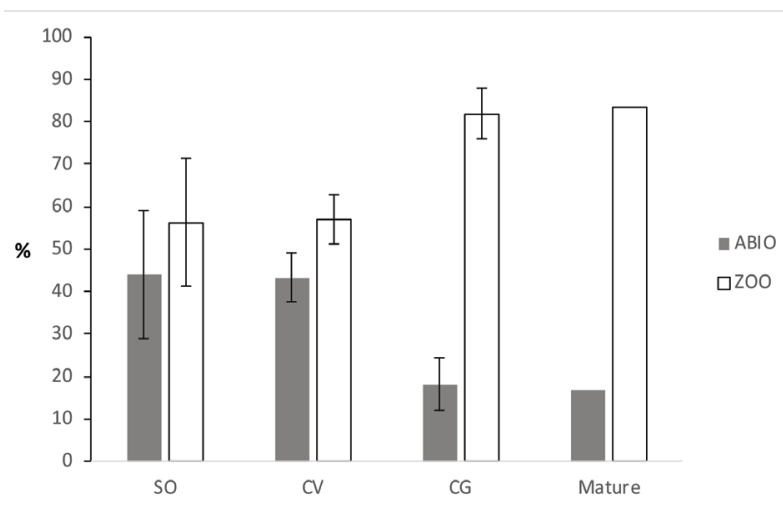

Figure 4 - Classification of the percentage of species by dispersal syndromes (abiotic and zoocoric) in the burnt forest fragments Sooretama (SO, 14-yrs after fire), Córrego do Veado (CV, 25-yrs after fire) and Córrego Grande (CG, 25-yrs after fire) and an adjacent mature forest (Paula and Soares 2011), ES, Brazil.

TABLE II

Structural parameters of the tree communities analyzed in the three forest fragments Sooretama (SO, 14 years after fire), Córrego do Veado (CV, 25 years after fire), Córrego Grande (CG, 25 years after fire) and in a mature forest (MF), State of Espírito Santo, Brazil. D = density/ha, BA = basal area $\left(\mathrm{m}^{2} / \mathrm{ha}\right)$, Vol = volume $\left(\mathrm{m}^{3} / \mathrm{ha}\right), \%$ Bifur = percent of bifurcated individuals and \% Stdead $=$ percent of standing dead individuals. The values in the same column followed by different letters are statistically different $(\mathbf{p} \leq \mathbf{0 . 0 5})$.

\begin{tabular}{cccccc}
\hline Site & D & BA & Vol & \% Bifur & \% Stdead \\
\hline SO & $1354 \pm 222 \mathrm{a}$ & $3.84 \pm 0.25 \mathrm{a}$ & $44.84 \pm 3.86 \mathrm{a}$ & $7.3 \pm 2.16 \mathrm{a}$ & $11.34 \pm 3.5 \mathrm{a}$ \\
CV & $1379 \pm 188 \mathrm{a}$ & $5.70 \pm 0.59 \mathrm{a}$ & $79.22 \pm 2.38 \mathrm{a}$ & $13.9 \pm 6.12 \mathrm{ab}$ & $4.18 \pm 2.3 \mathrm{~b}$ \\
CG & $1261 \pm 322 \mathrm{a}$ & $6.06 \pm 0.24 \mathrm{a}$ & $83.53 \pm 4.79 \mathrm{a}$ & $20.8 \pm 6.46 \mathrm{~b}$ & $5.84 \pm 2.6 \mathrm{~b}$ \\
MF & $1519^{1}$ & $47.15^{1}$ & - & $9.69^{2}$ & $5.59^{2}$ \\
\hline
\end{tabular}

${ }^{1}$ Paula and Soares 2011, ${ }^{2}$ Jesus and Rolim 2005.

The predominant dispersal syndrome of the species in all the sites was zoochoric, $68.2 \%$, compared to abiotic dispersal, $31.8 \%$. Among sties, CG had the highest percentage of zoochoric species (83\%), a value that was close to that observed in mature forests (Fig. 4).

\section{RECOVERY OF FOREST STRUCTURE AFTER FIRE}

The three burnt forest fragments had, in general, distinct structural values when compared to mature forest (Table II). The values of tree density and total basal area in the burnt forest fragments were much lower than the value found for mature forest, even for the fragments of 25 years after fire. The tree diameter distribution in the burnt forest fragments ( $\mathrm{SO}, \mathrm{CV}$ and $\mathrm{CG}$ ) indicated a higher density of individuals in classes with smaller DBH (5-10 $\mathrm{cm}$ and $10-15 \mathrm{~cm}$ ), with few trees having a DBH higher than $25 \mathrm{~cm}$ (Fig. 5), with no differences among fragments (Kolmogorov-Smirnov test, $\mathrm{p}>$ $0.05)$. Considering the mature forest, about $12 \%$ of trees were higher than $25 \mathrm{~cm} \mathrm{DBH}$, however, in the burnt forest fragments only $1.7 \%$ (SO), $4.2 \%(\mathrm{CV})$ and $6.2 \%(\mathrm{CG})$ of trees were large trees $(\mathrm{DBH}>25$ $\mathrm{cm})$. Among the burnt forest fragments, the main difference was in the number of standing dead trees that was higher at SO (Table II).

Approximately $83 \%$ of the live trees sampled had lianas. In the burnt forest fragments, the 


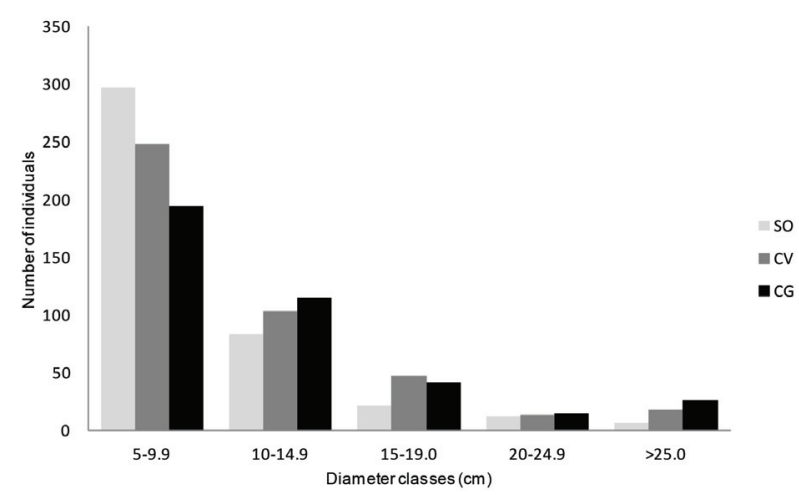

Figure 5 - Distribution of the number of individuals with $\mathrm{DBH} \geq 5 \mathrm{~cm}$ per diameter classes in the burnt forest fragments Sooretama (SO, 14-yrs after fire, $\mathrm{n}=1354$ ind.ha $^{-1}$ ), Córrego do Veado (CV, 25-yrs after fire, $\mathrm{n}=1379$ ind.ha $\left.^{-1}\right)$ and Córrego Grande (CG, 25-yrs after fire, $\mathrm{n}=1261$ ind.ha $\left.^{-1}\right)$, ES, Brazil.

TABLE III

Number of lianas on tree regeneration in the three forest fragments Sooretama (SO, 14 years after fire), Córrego do Veado (CV, 25 years after fire) and Córrego Grande (CG, 25 years after fire), State of Espírito Santo, Brazil. Absent $=$ without any liana/stem, Low $=1$ to 5 lianas/stem, Medium = 6 to 10 lianas/stem, High= More than 10 lianas stem.

\begin{tabular}{cccc}
\hline Presence of lianas & $\mathrm{SO}(\%)$ & $\mathrm{CV}(\%)$ & $\mathrm{CG}(\%)$ \\
\hline Absent & 9 & 16.6 & 24.4 \\
Low & 43.3 & 39 & 45.5 \\
Medium & 10.6 & 10 & 12 \\
High & 37.1 & 34.4 & 18.1 \\
\hline
\end{tabular}

predominant category was low infestation. However, SO had the highest percentage of individuals with lianas and the lowest without (Table III).

The ten species with the highest cover values differed among the burnt forest fragments. However, Annona dolabripetala (Annonaceae), Astronium concinnum (Anacardiaceae), Joannesia princeps (Euphorbiaceae) and Polyandrococos caudescens (Arecaceae) were always at the top of the list in these fragments. Although they were not within the ten most important species in mature forest (Table IV) with only Eriotheca macrophylla (Malvaceae) occurring in both list.

\section{DISCUSSION}

As expected, the lower species richness and diversity was found in the site SO (14-yrs after fire) which showed a higher percentage of pioneer species in comparison to the other two sites (25yrs after fire). However, species richness found at $\mathrm{SO}$ (94 species/0.31 ha, $\mathrm{DBH} \geq 5 \mathrm{~cm}$ ) can be considered high when compared to a burnt forest site in the same region that was sampled 10 years after a fire ( 33 species $/ 0.24$ ha, $D B H \geq 5 \mathrm{~cm})$ (Rolim and Jesus 2002). The large difference in species richness between the two sites after fire appears to be related to the fact that the site SO is located in a much larger forest fragment ( 28.000 ha vs 2400 ha) and it is within a forest dominated landscape.

Guariguata and Dupuy (1997) observed that recovery of species richness is slow in a disturbed tropical forest ( $\sim 80$-yrs) and is dependent on the type and intensity of the disturbance. However, based on the results of the present study (mean of 103 species/0.31 ha and 226 species/0.93 ha) a higher increase in species richness than expected was observed, since 265 tree species were reported in a hectare in an adjacent mature forest (Paula and Soares 2011). This relatively fast recovery in species composition might be related to the resprouting ability of some tree species. In this study, $14 \%$ of the individuals sampled were bifurcated, probably due to resprouting after the fire, a common strategy of many tree species and considered a fundamental process in the rapid recovery of degraded areas (Rodrigues et al. 2004).

The percentages of pioneer species in the study sites $(<20 \%)$ can be considered low and much different than the results found by S.G. Rolim (unpublished data) for two disturbed forests nearby our sites, one area with six years after a clear cut (91\% pioneers) and another area with 22 years after a clear cut (67\% pioneers). This difference in the number of pioneers seems to be related to the destruction of the soil seed bank by the fire. 
TABLE IV

List of the 10 most important species in cover values in the three forest fragments Sooretama (SO, 14 years after fire), Córrego do Veado (CV, 25 years after fire), Córrego Grande (CG, 25 years after fire) and a mature forest (MF), State of Espírito Santo, Brazil. MF data from Paula and Soares (2011).

\begin{tabular}{|c|c|c|c|c|}
\hline Species & SO & $\mathrm{CV}$ & CG & MF \\
\hline Annona dolabripetala Raddi & 14.02 & 4.66 & 13.27 & - \\
\hline Astrocaryum aculeatissimum Schott (Burret) & - & - & 4.01 & - \\
\hline Astronium concinnum Schott & 13.01 & 10.98 & - & - \\
\hline Astronium graveolens Jacq. & 3.06 & - & - & - \\
\hline Bixa arborea Huber & 3.68 & - & - & - \\
\hline Brasiliocroton mamoninha P.E. Berry \& Cordeiro & 4.96 & 2.80 & - & - \\
\hline Cecropia hololeuca Miq. & 6.10 & - & - & - \\
\hline Cordia trichotoma (Vell.) Arráb. ex Steud. & 3.16 & - & - & - \\
\hline Coussapoa curranii S.F.Blake & - & - & - & 5.14 \\
\hline Cupania cf. racemosa (Vell.) Radlk. & - & - & 2.70 & - \\
\hline Deguelia costata (Benth.) A.M.G. Azevedo \& R.A. Camargo & - & 5.94 & - & - \\
\hline Dialium guianense (Aubl.) Sandwith & - & - & - & 5.35 \\
\hline Eriotheca macrophylla (K. Schum.) A. Robyns & - & - & 2.19 & 11.41 \\
\hline Eugenia ubensis Cambess. & - & - & - & 3.87 \\
\hline Ficus gomelleira Kunth & - & - & - & 8.33 \\
\hline Goniorrhachis marginata Taub. & - & 5.11 & - & - \\
\hline Guatteria sellowiana Schltdl. & - & - & 2.33 & - \\
\hline Guazuma crinita Mart. & - & 3.42 & - & - \\
\hline Hydrogaster trinervis Kuhlm. & - & - & - & 5.80 \\
\hline Inga subnuda Salzm. ex Benth. & - & - & 4.33 & - \\
\hline Joannesia princeps Vell. & 4.75 & 7.32 & - & - \\
\hline Luehea divaricata Mart. \& Zucc. & 3.74 & - & - & - \\
\hline Machaerium fulvovenosum H.C.Lima & - & 4.98 & - & - \\
\hline Melanoxylon brauna Schott & - & 2.83 & - & - \\
\hline Pogonophora schomburgkiana Miers ex Benth. & - & - & 3.33 & - \\
\hline Allagoptera caudescens (Mart.) Kuntze & 5.15 & 6.88 & - & - \\
\hline Protium heptaphyllum (Aubl.) Marchand & - & - & 5.46 & - \\
\hline Pterocarpus rohrii Vahl & - & - & - & 3.93 \\
\hline Rinorea bahiensis (Moric.) Kuntze & - & - & - & 15.30 \\
\hline Sterculia speciosa K.Schum. & - & - & - & 6.87 \\
\hline Tapirira guianensis Aubl. & - & - & 13.70 & - \\
\hline Terminalia kuhlmannii Alwan \& Stace & - & - & - & 3.67 \\
\hline Thyrsodium spruceanum Benth. & - & - & 3.96 & - \\
\hline
\end{tabular}


Van Nieuwstadt et al. (2001) found that a severe fire could reduce by $85 \%$ the viability of seeds in the soil seed bank. Local residents reported that in our burnt sites fire was intense and lasted several days. Thus, it appears that this event destroyed the soil seed bank, eliminating seeds of pioneer species that in general have dormancy and use a "waiting" strategy for the opening of a canopy gap and a large increase in light intensity to stimulate germination (Dalling et al. 1997).

Saldarriga et al. (1988), using the equation $\ln$ $\mathrm{Y}=1.75+0.34 \ln (\mathrm{X})$ where $\mathrm{Y}$ is the mean basal area $\left(\mathrm{m}^{2} \cdot \mathrm{ha}^{-1}\right)$ and $\mathrm{X}$ is age (years), estimated that approximately 190 years would be necessary for abandoned agricultural areas to attain a value of basal area similar to mature forests $\left(35 \mathrm{~m}^{2} \cdot \mathrm{ha}^{-1}\right)$. This premise is corroborated by the data in the present study. Applying the formula proposed by Saldarriga et al. (1988) and considering that CG and $\mathrm{CV}$ were disturbed 25 years ago, the expected result would be a basal area of $5,9 \mathrm{~m}^{2} / \mathrm{ha}$ and the results found for CV and CG were 5.7 and $6.1 \mathrm{~m}^{2} /$ ha, respectively. Thus, it is interesting to note that although this formula is based on data collected in Amazonian forests of the upper Rio Negro, in Colombia and Venezuela, it appears to be adequate for applying in the seasonal semideciduous forest in the north of the State of Espírito Santo. So, the recovery of disturbed areas to values close to those observed in mature forests $\left(30 \mathrm{~m}^{2} \mathrm{ha}^{-1}\right.$, Rolim and Jesus (2002) and $47.15 \mathrm{~m}^{2} \mathrm{ha}^{-1}$, Paula and Soares (2011) would take 190 to 300 years after fire.

The low bifurcation/resprouting rate observed in this study and the small number of remnant trees $(\mathrm{DBH}>30 \mathrm{~cm})$, suggest that most tree species in this forest type does not have fire tolerance. The most important post-fire species were different, as would be expected, from the main species that occur in mature forests. Among the species with the highest cover values in the mature forest are Rinorea bahiensis (Violaceae), Hidrogaster trinervis (Malvaceae), Senefeldera multiflora
(Euphorbiaceae), Dialium guianensis (Fabaceae) and Terminalia kuhlmannii (Combretaceae) (Jesus and Rolim 2005, Paula and Soares 2011) and none of these were reported as an important species in the three sites studied. Thus, 25 years after the fire the natural regeneration process indicates that the occurrence of resprouting and survival post-fire of individuals in the study areas appears to have favored another group of species and not those species that occur with the highest cover values in the mature forest.

\section{ACKNOWLEDGMENTS}

We gratefully acknowledge the Instituto Chico Mendes (ICMBIO) in ensuring access to sites and its local staff of the Rebio Sooretema, Rebio Córrego do Veado and Rebio Córrego Grande for logistic support. Geovane Siqueira provided invaluable assistance in plant identification. We also thank Luciana Thomas and John Hay for comments that improved the early version of the manuscript. Conselho Nacional de Desenvolvimento Científico e Tecnológico ( $\mathrm{CNPq}$ ) provided a productivity grant to Marcelo Trindade Nascimento and Coordenação de Aperfeiçoamento de Pessoal de Nível Superior (CAPES) provided the master scholarship of Mayke Blank Costa.

\section{REFERENCES}

APG - ANGIOSPERM PHYLOGENY GROUP. 2016. An update of the Angiosperm Phylogeny Group classification for the orders and families of flowering plants: APG IV. Bot J Linn Soc 181: 1-20.

BANDA-R K, DELGADO-SALINAS A, DEXTER KG, LINARES-PALOMINO R, OLIVEIRA-FILHO A, PRADO D AND PENNINGTON RT. 2016. Plant diversity patterns in neotropical dry forests and their conservation implications. Science 353(6306): 1383-1387.

BROWER JE AND ZAR JH. 1984. Field and laboratory methods for general ecology. Iowa: Wm. Brown Company, $225 \mathrm{p}$.

CORLETT R AND PRIMACK R. 2011. Tropical Rain Forests: An Ecological and Biogeographical Comparison. Oxford: Wiley-Blackwell, $336 \mathrm{p}$. 
DALLING JW, SWAINE MD AND GARWOOD NC. 1997. Soil seed bank dynamics in seasonally moist lowland tropical forest, Panama. J Trop Ecol 13: 659-680.

EMBRAPA. 1978. Mapa exploratório dos solos do Estado do Espírito Santo. http://mapoteca.cnps.embrapa.br/default. aspx. Acesso em 7 de Dezembro de 2013.

GANDOLFI S, LEITÃO FILHO HF AND BEZERRA CLE. 1995. Levantamento florístico e caráter sucessional das espécies arbustivo-arbóreas de uma floresta mesófila semidecídua no município de Guarulhos, SP. Rev Bras Biol 55: 753-767.

GOTELLI NJ AND ENTSMINGER GL. 2001. EcoSim: Null models software for ecology, version 7. http://www. garyentsminger.com/ecosim.htm. Accessed on November 12, 2012.

GUARIGUATA MR AND DUPUY JM. 1997. Forest regeneration in abandoned logging roads in lowland Costa Rica. Biotropica 29: 15-28.

HAMMER Ø, HARPER DAT AND RYAN PD. 2001. PAST: paleontological statistics software package for education and data analysis. Palaeontol Electronic 4: 1-9.

IBGE. 2012. Manual Técnico da vegetação Brasileira. Rio de Janeiro: IBGE, $271 \mathrm{p}$.

JANZEN DH. 1988. Management of habitat fragments in a tropical dry forest: growth. Ann Mo Bot Gard 75: 105-116.

JESUS RM, RODRIGUES FCMP AND ROLIM SG. 2010. Pesquisas em sementes florestais na Reserva Natural Vale. $1^{\text {a }}$ ed., Rio de Janeiro: Movimentos Artes Gráficas Ltda.

JESUS RM AND ROLIM SG. 2005. Fitossociologia da Mata Atlântica de Tabuleiro. Boletim Técnico SIF 19: 1-149.

KENT M AND COKER P. 1992. Vegetation Description and Analysis. Folia Geobot 36: 101-103.

KÖPPEN W. 1946. Das geographische System der Klimate. In: Köppen W and Geiger W (Eds), Handbuch der Klimatologie. Berlin: Gebr. Borntrager.

LIBANO AM AND FELFILI JM. 2006. Mudanças temporais na composição florística e na diversidade de um cerrado sensu stricto do Brasil Central em um período de 18 anos (1985-2003). Acta Bot Bras 20: 927-936.

MILES L, NEWTON AC, DEFRIES RS, RAVILIOUS C, MAY I, BLYTH S, KAPOS V AND GORDON JE. 2006. A global overview of the conservation status of tropical dry forests. J Biogeogr 33: 491-505.

MURPHY PG AND LUGO AE. 1986. Ecology of tropical dry forest. Annu Rev Ecol Syst 17: 67-88.
OLIVEIRA-FILHO AT, CARVALHO DA, VILELA EA, CURI N AND FONTES MAL. 2004. Diversity and structure of the tree community of a fragment of tropical secondary forest of the Brazilian Atlantic Forest domain 15 and 40 years after logging. Rev Bras Bot 27: 685-701.

PAULA A AND SOARES JJ. 2011. Estrutura horizontal de um trecho de floresta ombrófila densa das terras baixas na Reserva Biológica de Sooretama, Linhares, ES. Floresta 41: 321-334.

POWERS JS, BECKNEL JM, IRVING J AND AVILES DP. 2009. Diversity and structure of regenerating tropical dry forests in Costa Rica: Geographic patterns and environmental drivers. Forest Ecol Manag 258: 959-970.

QUESADA M ET AL. 2009. Succession and Management of Tropical Dry Forests in the Americas: Review and New Perspectives. Forest Ecol Manag 258: 1014-1024.

RODRIGUES RR, TORRES RB, MATTHES LAF AND PENHAAF. 2004. Tree species resprouting from root buds in a semideciduous forest affected by fires, Campinas, southeast Brazil. Braz Arch Biol Techn 47: 127-133.

ROLIM SG AND JESUS RM. 2002. A sucessão florestal na Reserva Biológica do Córrego do Veado (ES) após 10 anos de incêndio florestal. In: III Congresso Brasileiro de Unidades de Conservação, 1, 2002. Anais... Fortaleza: Rede Nacional Pró-Unidades de Conservação/Fundação o Boticário de Proteção à Natureza, p. 534-544.

SALDARRIAGA JG AND UHL C. 1991. Recovery of forest vegetation following slash-and-burn agriculture in the upper Rio Negro. In: Gomez-Pompa A, Whitmore TC and Hadley M (Eds), Tropical rain forest: regeneration and management. New York: Blackwell, p. 303-312.

SALDARRIGA JG, WEST ML, THARP ML AND UHL C. 1988. Long-term chronosequence of forest succession in the upper Rio Negro of Colombia and Venezuela. J Ecol 76: 938-958.

VAN DER PIJL L. 1982. Principles of dispersal in higher plants. Berlin: Springer Verlag, $218 \mathrm{p}$.

VAN NIEUWSTADT MGL, SHEIL D AND KARTAWINATA K. 2001. The ecological consequences of logging in the burned forests of East Kalimantan, Indonesia. Conserv Biol 15: 1183-1186.

VIEIRA DLM AND SCARIOT A. 2006. Principles of natural regeneration of tropical dry forests for restoration. Restor Ecol 14: 11-20. 